\title{
Antiviral treatment in severe acute hepatitis B
}

\author{
Anca Streinu-Cercel ${ }^{1,2^{*}}$, Oana Streinu-Cercel ${ }^{1,2}$, Alina Cristina Negut ${ }^{1,2}$, Marius Stefan ${ }^{3}$, Adrian Streinu-Cercel ${ }^{1,2}$ \\ From Abstracts from International Symposium HIV and Emerging Infectious Diseases 2014 \\ Marseille, France. 21-23 May 2013
}

\section{Introduction}

We aimed to evaluate the clinical, biological and virological impact of antiviral therapy in severe acute hepatitis B. [1]

\section{Materials and methods}

We performed a study in the National Institute for Infectious Diseases "Prof. Dr. Matei Bals", Bucharest, Romania, randomizing patients between two groups initially: therapy with lamivudine $100 \mathrm{mg}$ /day vs. standard of care (no antiviral therapy) and subsequently between three groups: lamivudine, standard of care and entecavir $0.5 \mathrm{mg} /$ day, when this new analogue became available in Romania.

\section{Results}

HBs antigen to antibody seroconversion was recorded by 24 weeks in $10.1 \%$ of the patients in the lamivudine group ( $\mathrm{p}=0.032$ compared to control), $42.9 \%$ of those in the entecavir group ( $\mathrm{p}=0.053$ compared to control), and $22.7 \%$ in the control (standard of care) group.

\section{Conclusions}

If antiviral therapy is to be considered in severe acute hepatitis B, entecavir could be regarded as an option, as it might increase the chance of HBs antigen to antibody seroconversion when administered in the first 24 weeks of infection. [2,3] However, further studies are required to ascertain this, and to eventually determine the magnitude of the effect.

\section{Authors' details}

${ }^{1}$ Department of Infectious Diseases, Carol Davila University of Medicine and Pharmacy, Bucharest, Romania. ${ }^{2}$ National Institute for Infectious Diseases, Bucharest, Romania. ${ }^{3}$ Polytechnic University of Bucharest, Romania.

Published: 23 May 2014

Department of Infectious Diseases, Carol Davila University of Medicine and Pharmacy, Bucharest, Romania

Full list of author information is available at the end of the article

\section{References}

1. Streinu-Cercel A: Hepatitis B in the spotlight. GERMS 2011, 1(1):5.

2. De Socio GV, Sgrelli A, Tosti A, Baldelli F: Severe acute hepatitis B treated with entecavir. Mediterr J Hematol Infect Dis 2011, 3(1):e2011010.

3. Streinu-Cercel O, Streinu-Cercel A, Preotescu LL, Streinu-Cercel A: Entecavir as specific antiviral therapy in selected cases of severe acute hepatitis $B$. GERMS 2012, 2(1):18-22.

\section{doi:10.1186/1471-2334-14-S2-P90}

Cite this article as: Streinu-Cercel et al: Antiviral treatment in severe acute hepatitis B. BMC Infectious Diseases 2014 14(Suppl 2):P90.

\section{Submit your next manuscript to BioMed Central and take full advantage of: \\ - Convenient online submission \\ - Thorough peer review \\ - No space constraints or color figure charges \\ - Immediate publication on acceptance \\ - Inclusion in PubMed, CAS, Scopus and Google Scholar \\ - Research which is freely available for redistribution \\ Submit your manuscript at www.biomedcentral.com/submit}

